\title{
PROFILE OF PATIENTS WITH BRAIN ABSCESS
}

\author{
Khatiwada $R^{1^{*}}$, Bista $P^{2}$, Jha $R^{3}$, Khadka $N K^{4}$, Shrestha $R^{5}$, Khambu $B^{5}$
}

\begin{abstract}
Affiliation
1. Department of Neurosurgery, NAMS, Bir Hospital, Kathmandu

2. Professor, Head of Department of Neurosurgery, National Academy of Medical Sciences, Kathmandu, Nepal

3. Professor, Department of Neurosurgery, National Academy of Medical Sciences, Kathmandu, Nepal

4. Associate Professor, Department of Neurosurgery, National Academy of Medical Sciences, Kathmandu, Nepal

5. Assistant Professor, Department of Neurosurgery, National Academy of Medical Sciences, Kathmandu, Nepal
\end{abstract}

\section{ARTICLE INFO}

Received : 2 October, 2020
Accepted : 25 November, 2020
Published : 22 December, 2020

(C) Authors retain copyright and grant the journal right of first publication with the work simultaneously licensed under Creative Commons Attribution License CC - BY 4.0 that allows others to share the work with an acknowledgment of the work's authorship and initial publication in this journal.

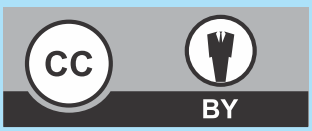

ORA 211

DOI: https://doi.org/10.3126/bjhs.v5i3.33702

* Corresponding Author

Dr. Roshan Khatiwada

MCh Neurosurgery Resident

National Academy of Medical Science, Kathmandu, Nepal

Email ID: roshankhatiwada@gmail.com

ORCID ID: https://orcid.org/0000-0002-3051-1886

\section{Citation}

Khatiwada R, Bista P, Jha R, Khadka NK, Shrestha R, Khambu B. Profile of Patients with Brain Abscess. BJHS 2020;5(3)13. 1220-1223.

\section{ABSTRACT \\ Introduction}

Despite of the advent of modern neurosurgical techniques and antibiotics, brain abscess possesses a major neurosurgical challenge in treatment. In this study we present the profile, clinical features, radiological features, treatment received and their outcome of cases of brain abscess that we managed in our center.

\section{Methodology}

Total 30 patients diagnosed with brain abscess who underwent treatment in last four months were included in this study. A descriptive observational data of brain abscess and the outcome variables in the form of Glasgow Outcome Scale (GOS) at discharge, hospital stay, and mortality were studied. The ultimate outcome was measured in Glasgow Outcome Score.

\section{Result}

Total number of cases was 30, out with male dominance 19 (63.3\%). Age ranged from 2 months to 60 years. Twenty-five patients were of acute pyogenic abscess while and rest were tubercular abscess. Common clinical features were headache $(70 \%)$, fever $(30 \%)$, vomiting $(23 \%)$, seizure $(23 \%)$ and focal neurological deficits (16.7\%). Overall mean hospital stay was 31 days. The common aetogenic factors included chronic suppurative otitis media (16.7\%), tuberculosis $(16.7 \%)$, post-traumatic $(10 \%)$, congenital heart disease $(10 \%)$ and rest $(46 \%)$ were of unknown source. lobe Temporal lobe and cerebellar were most common site involved (20\%) each followed by frontal (16.7\%). Surgery was done in 25 (83.3\%) cases out of which 12 underwent burr hole and aspiration and 12 patients underwent craniotomy and excision and one patient underwent burr hole and followed by craniotomy. Five patients were managed conservatively. Complete resolution of abscess with complete recovery of preoperative neurological-deficit was seen n 28 (93.3\%) cases.

\section{Conclusion}

Early diagnosis and timely intervention improves the outcome of brain abscess. Most of the cases required surgical intervention and drainage of pus and had good postoperative outcome.

\section{KEYWORDS}

Brain abscess, burr hole, craniotomy, CSOM, excision, pyogenic, tubercular. 


\section{INTRODUCTION}

Brain abscess is an intra-parenchymal collection of pus. The incidence of brain abscess is approximately $8 \%$ of intracranial masses in developing countries and $1-2 \%$ in the western countries. ${ }^{1,2}$ They begin as localized areas of cerebritis in the parenchyma and evolve into collections of pus enclosed by an well vascularized capsule. Although there have been breakthrough advances in neuroimaging, neurosurgical techniques, neuro anesthesia, microbiological isolation techniques and antibiotic therapy, bacterial brain abscesses can be fatal. ${ }^{3-6}$ However, the advent of modern neurosurgical techniques including stereotactic aspiration, better anaerobic culture techniques, newer generation antibiotics, and modern non-invasive neuro radiological imaging procedures have revolutionized the treatment and outcome of brain abscess. Eradication of the primary foci of infection is paramount. ${ }^{3,8,9}$

The success of treatment is best when the causative agent is identified and antimicrobial therapy is targeted. The causative pathogens of bacterial brain abscesses vary according to geographic location, age, underlying medical and/or surgical condition, and mode of infection. ${ }^{5,8,10-12}$ Over the period of last 10-15 years. The incidence of otogenic abscess is in decline since last one and half decades while the post traumatic or postoperative brain abscess has increased. ${ }^{13-15}$

Patients with brain abscess are regularly treated in our center but their clinical and radiological profile and the treatment outcome has not been reported. So present study will evaluate these parameters and causative microorganisms and guide us to implement better treatment protocol for patients with brain abscess according to recent advancements in diagnostic equipment like high resolution $\mathrm{CT}$ and $\mathrm{MRI}$ and modern technologies such as neuronavigation and streotaxy.

\section{METHODOLOGY}

Descriptive observational study conducted in Department of Neurosurgery Bir Hospital and National Trauma Center. All patients who were managed with diagnosis of brain abscess were included in the study. Total 30 patients who were treated during the period of four months and were followed up in OPD . CT scan was carried out on all patients on the finding of clinical features referable to the nervous system or focal neurological deficits and features of raised intracranial pressure, i.e. headache, hemiparesis, seizures, vomiting, papilledema, etc. A hypo dense mass with an encircling ring of contrast enhancement-usually associated with perilesional edema and mass effect - on brain CT confirms the diagnosis of abscess and precludes likely differential diagnoses. All patients with brain abscess of size less then $2 \mathrm{~cm}$ in maximum dimension volume $<20 \mathrm{ml}$ in supratentorial lesion and $<10 \mathrm{ml}$ in infratentorial lesion were managed with intravenous antibiotics for 6 weeks. If the size was greater than that, patient underwent burr hole and evacuation and i.v. antibiotics. CT head was repeated in 2 weeks. The CT findings and the treatment details were recorded and outcome factor taken as Glasgow Outcome Scale of patients at the time of discharge was documented.

\section{Glassgow Outcome Scale}

\begin{tabular}{|c|l|}
\hline GOS & \multicolumn{1}{|c|}{} \\
\hline V & $\begin{array}{l}\text { GOOD RECOVERY Resumption of normal } \\
\text { activities even though there may be minor } \\
\text { neurological or psychological deficits. }\end{array}$ \\
\hline IV & $\begin{array}{l}\text { MODERATE DISABILITY (Disabled but } \\
\text { independent). Patient is independent as far } \\
\text { as daily life is concerned. The disabilities } \\
\text { found include varying degrees of dysphasia, } \\
\text { hemiparesis, or ataxia, as well as intellectual } \\
\text { and memory deficits and personality changes. }\end{array}$ \\
\hline III & $\begin{array}{l}\text { SEVERE DISABILITY (Conscious but disabled). } \\
\text { Patient depends upon others for daily } \\
\text { support due to mental or physical disability or } \\
\text { both. }\end{array}$ \\
\hline II & $\begin{array}{l}\text { PERSISTENT VEGETATIVE STATE Patient } \\
\text { exhibits no obvious cortical function }\end{array}$ \\
\hline I & DEATH \\
\hline
\end{tabular}

GOS V ,IV ,III was considered as favourable outcome and GOSI,II was considered as unfavourable outcome. Statistical analysis was done by applying appropriate statistical test with recent version of SPSS software.

\section{RESULTS}

Total 30 patients with brain abscess were included in this series out of which 19 patients were male, mean age of presentation was 22.6 years and range were two months to 60 years.

Table 1. Age and sex distribution of intracranial abscess
\begin{tabular}{|llll|}
\hline Age(yrs.) & Male (\%) & Female (\%) & Total (\%) \\
\hline $0-14$ & $5(16.6)$ & $5(16.6)$ & $10(33.3)$ \\
\hline $15-29$ & $7(23.3)$ & $4(13.3)$ & $11(36.6)$ \\
\hline $30-44$ & $2(6.6)$ & $0(0)$ & $2(6.6)$ \\
\hline $45-59$ & $5(16.6)$ & $1(3.3)$ & $6(20)$ \\
\hline$>60$ & $0(0)$ & $1(3.3)$ & $1(3.3)$ \\
\hline Total & $19(63.3)$ & $11(36.7)$ & $30(100)$ \\
\hline
\end{tabular}

Table 2. Clinical Features
\begin{tabular}{|ll|}
\hline Clinical features & (\%) \\
\hline Headache & $21(70 \%)$ \\
\hline Fever & $9(30 \%)$ \\
\hline Vomiting & $7(23 \%)$ \\
\hline Seizure & $7(23 \%)$ \\
\hline Neurological Deficits & $6(16.3 \%)$ \\
\hline
\end{tabular}

Most common clinical features at presentation was headache $(70 \%)$, fever was present in $30 \%$, which was followed by vomiting in $23 \%$. Seizure was present in $23 \%$ and $16.3 \%$ presented with neurological deficits ie; weakness of limbs. Mean hospital stay was 31 days overall, 28 days $n$ burrhole and aspiration group and 25 days in craniotomy and excision group whereas in conservative group it was 46 days. 
Table 3. Radiological features of brain abscess

\begin{tabular}{|l|ll|}
\hline \multirow{2}{*}{ Number } & Single & $26(86.7 \%)$ \\
\cline { 2 - 3 } & Multiple & $4(13.3 \%)$ \\
\hline \multirow{2}{*}{ Site } & Supra-tentorial & $24(80 \%)$ \\
\cline { 2 - 3 } & Infra-tentorial & $6(20 \%)$ \\
\hline \multirow{2}{*}{ Side } & Left & $15(50 \%)$ \\
\cline { 2 - 3 } & Right & $15(50 \%)$ \\
\hline
\end{tabular}

In radiological imaging $26(86.7 \%)$ were single and rest were multiple. Most of them were supratentorial 24 (80\%). 12 (40\%) patients were managed by burr hole and aspiration, $12(40 \%)$ patients underwent craniotomy and excision. One patient initially managed by burr hole and aspiration underwent craniotomy and excision due to no resolution of lesion. $5(16.7 \%)$ were treated with only intravenous antibiotics. Out of total patients 28 (93\%) patient were discharged with good outcome and $2(7 \%)$ patients had mortality. Out of two mortalities both patients were treated by burr hole and aspiration. One patient developed ventriculitis and the other died due to septic shock due to delayed presentation in our center.

Table 4. Treatment Modalities of Brain Abscess
\begin{tabular}{|lc|}
\hline Procedure & N $(\%)$ \\
\hline Burr Hole and Aspiration & $12(40 \%)$ \\
\hline Craniotomy and Excision of Abscess & $12(40 \%)$ \\
\hline $\begin{array}{l}\text { Both burr hole and Craniotomy and } \\
\text { Excision }\end{array}$ & $1(3.3 \%)$ \\
\hline IV Antibiotics only & $5(16.7 \%)$ \\
\hline Table 5. Conditions at Discharge & \\
\hline Glasgow Outcome Scale & N (\%) \\
\hline I(Death) & $2(6.7 \%)$ \\
\hline II(Persistent Vegetative State) & 0 \\
\hline III(Severe Disability) & 0 \\
\hline IV(Moderate Disability) & $3(10 \%)$ \\
\hline V(Good Recovery) & $25(83 \%)$ \\
\hline
\end{tabular}

Table 6. Comparision of Different Treatment Modalities and Their Outcome

\begin{tabular}{|c|c|c|}
\hline \multirow[b]{2}{*}{ Treatment Modalities } & \multicolumn{2}{|c|}{ Outcome } \\
\hline & $\begin{array}{l}\text { Favourable } \\
\text { (GOSV,IV) }\end{array}$ & $\begin{array}{l}\text { Unfavourable } \\
\text { ( GOS ,II,III) }\end{array}$ \\
\hline IV antibiotics & 5 & 0 \\
\hline Burr Hole and drainage & 10 & 2 \\
\hline Craniotomy and Excision & 12 & 0 \\
\hline $\begin{array}{l}\text { Both burr hole and } \\
\text { craniotomy and excision }\end{array}$ & 1 & 0 \\
\hline
\end{tabular}

\section{DISCUSSION}

Out of total 30 patients with brain abscess 25 were managed surgically. Brain abscess was more common in male $19(63 \%)$. This may be due to discrimination in seeking medical advice on the basis of sex by local population and exposure of male population to trauma. Mean age of presentation was 22.6 years. Most of the patients were in first three decades of life ie; $21(70 \%)$. This finding was in congruence with most other studies like Singh et al ${ }^{16}$ (2017) as $73 \%$. Gupta et al $(1990)^{17}$, Menon and Bhardwaj et $a^{18}$ (2008) also showed high incidence in first two decades of life as 67 years. Patients with brain abscess presented mostly with headache (70\%), fever was present in $30 \%$, which was followed by vomiting in $23 \%$. Seizure was present in $23 \%$ and $16.3 \%$ presented with neurological deficits ie; weakness of limbs.

In most of the large series of brain abscess from developing countries, CSOM still remains to be the commonest source of intracranial abscess. In our study common aetiological factors were CSOM and tuberculosis are both equal (16.7\%) followed by trauma (10\%). Similar results have been reported in other studies from India by Bhardwaj and Joshi ${ }^{19}$ (1998) and Lakshmi et $\mathrm{al}^{20}$ (1993). While in developed countries the incidence of CSOM had come down to $0.04 \%$ (Osma et al, 2000) and trauma has been increasing cause of brain abscess.

Out of them $86 \%$ were had single lesion and $14 \%$ had multiple. Eighty percent were supratentorial and $20 \%$ were infra-tentorial. Commonest lobe was temporal and cerebellar which were associated with CSOM followed by frontal. In a study carried out by Cavuşoglu $\mathrm{H}$ et $\mathrm{al}^{21}$, the temporoparietal region was the most commonly affected location like in our study.

Equal number of patients, 12 each were treated by burr hole and aspiration and craniotomy and excision. One patient had undergone burr-hole aspiration followed by craniotomy and excision. All the patients treated by craniotomy and excision had good outcome whereas 2 (16\%) patients treated by burrhole and aspiration had mortality due to ventriculitis and septic shock. Five patients treated with iv antibiotics had good recovery. Xiao et al ${ }^{22}$ reported similar effectiveness between the two procedures, but significantly lower mortality $(p=0.02)$ with open craniotomy excision.

\section{CONCLUSION}

CSOM and tuberculosis are most common cause of brain abscess followed by trauma in our region. Most of the cases required surgical intervention and drainage of pus and had good postoperative outcome. Patient managed with craniotomy and excision had better outcome than those managed by burr hole and aspiration and also had shorter hospital stay. Patient who presented in comatose state had bad outcome. Early diagnosis and appropriate interventions improves the outcomes of brain abscess.

\section{RECOMMENDATION}

Early diagnosis and appropriate interventions improves the outcomes of brain abscess. Any patients presenting with neurological features suggestive of brain abscess should be evaluated with adequate suspicion along with necessary radiological evalution and prompt treatment should be started. 


\section{LIMITATIONS OF THE STUDY}

This study is done at the tertiary referral centre so the results cannot be generalized. The study period and sample size is small.

\section{CONFLICT OF INTREST}

None

FINANCIAL DISCLOSURE

None

\section{REFERENCES}

1. Osenbach RK, Loftus CM. Diagnosis and management of brain abscess. Neurosurg Clin N Am. 1992;3(2):403-420. PMID: 1633468

2. Sharma BS, Gupta SK, Khosla VK. Current concepts in the management of pyogenic brain abscess. Neurol India 2000;48:10511.

3. Lu CH, Chang WN, Lui CC. Strategies for the management of bacterial brain abscess. J Clin Neurosci 2006;13:979-85. PMID: 17056261

4. Takeshita M, Kagawa M, Izawa M, Takakura K. Current treatment strategies and factors influencing outcome in patients with bacterial brain abscess. Acta Neurochir (Wien) 1998;140:1263-70. DOI :10.1007/s007010050248

5. Tekkök IH, Erbengi A. Management of brain abscess in children. Review of 130 cases over a period of 21 years. Childs Nerv Syst 1992;8:411-6. DOI: 10.1007/BF00304791

6. Yang SY. Brain abscess: a review of 400 cases. J Neurosurg 1981;55:794-9. PMID: 7310502

7. Kao PT, Tseng HK, Liu CP, Su SC, Lee CM. Brain abscess: clinical analysis of 53 cases. J Microbiol Immunol Infect 2003;36:129-36. PMID: 12886965

8. Xiao F, Tseng MY, Teng LJ, Tseng HM, Tsai JC. Brain abscess: clinical experience and analysis of prognostic factors. Surg Neurol 2005;63:442-50. PMID: 15883068

9. Osenbach RK, Loftus CM. Diagnosis and management of brain abscess. Neurosurg Clin N Am 1992;3:403-20. PMID: 1633468

10. Ciurea AV, Stoica F, Vasilescu G, Nuteanu L. Neurosurgical management of brain abscesses in children. Childs Nerv Syst 1999;15:309-17. PMID: 10461779

11. Szuwart U, Bennefeld H. Bacteriological analysis of pyogenic infections of the brain. Neurosurg Rev 1990;13:113-18. PMID: 1971093

12. Britt RH. Brain abscess. In: Wilkins RH, Rengachary SS, editors. Neurosurgery, vol 3. New York: McGraw-Hill; 1985. p. 1928-56.

13. Carpenter J, Stapleton S, Holliman R. Retrospective analysis of 49 cases of brain abscess and review of the literature. Eur J Clin Microbiol Infect Dis 2007;26:1-11. PMID: 17180609
14. Goodkin HP, Harper MB, Pomeroy SL. Intracerebral abscess in children: historical trends at Children's Hospital Boston. Pediatrics 2004;113:1765-70. PMID: 15173504

15. McCaig LF, Besser RE, Hughes JM. Trends in antimicrobial prescribing rates for children and adolescents. JAMA 2002;287:3096-102. PMID: 12069672

16. Singh N, Singh DK, Kumar R, Prajapati $H$. Current epidemiological trends of brain abscess: A clinicopathological study. roneuro [Internet]. 2017Sep.15 [cited 2020Sep.14];31(3):414-21. Available from: https://www.journals.lapub.co.uk/index.php/roneurosurgery /article/view/1030

17. Sharma, B. S., Gupta, S. K., \& Khosla, V. K. (2000). Current concepts in the management of pyogenic brain abscess. Neurology India, 48(2), 105-111. PMID: 10878771

18. Menon, S., Bharadwaj, R., Chowdhary, A., Kaundinya, D. V., \& Palande, D. A. (2008). Current epidemiology of intracranial abscesses: a prospective 5 year study. Journal of medical microbiology, 57 (Pt 10), 1259-1268. PMID: 18809555

19. Bharadwaj, R. \& Joshi, B. N. (1988). Brain abscesses - a study of the causative organisms with special reference to anaerobes. Indian J Pathol Microbiol 31, 44-48. PMID: 3169915

20. Lakshmi, V., Umabala, P., Anuradha, K., Padmaja, K., Padmasree, C., Rajesh, A., \& Purohit, A. K. (2011). Microbiological spectrum of brain abscess at a tertiary care hospital $n$ South ndia: 24-year data and review. Pathology research nternational, 2011, 583139. PMID: 22191080

21. Cavuşoglu, H., Kaya, R. A., Türkmenoglu, O. N., Colak, ., \& Aydin, Y. (2008). Brain abscess: analysis of results $n$ a series of 51 patients with a combined surgical and medical approach during an 11-year period. Neurosurgical focus, 24(6), E9. PMID: 18518754

22. Xiao F, Tseng MY, Teng L et al (2005). Brain abscess: clinical experience and analysis of prognostic factors. Surg Neurol 63:442-449. PMID: 15883068 